\title{
Editorial
}

\section{Eysenck and Wolpe: Not the End of an Era}

This issue contains the obituaries of two of the greats in our field, and it is tempting to regard it as the end of an era. Hans Eysenck and Joseph Wolpe were truly giants in the field, truly founding fathers of scientific cognitive-behavioural therapy. Their passing is a landmark, but clearly not the end of an era. The era that they ushered in was one in which the basis of psychopathology and treatment lay in well defined theory and rigorous, well conducted research. That philosophy has grown, developed, and has given us a scientific basis for cognitive-behavioural therapy.

I believe that it is no coincidence that both men intended, at an early age, to follow a career in the physical sciences. They had many other characteristics in common, including a firmness of purpose that served both them and the field well. Isaac Newton, writing to Robert Hooke, said of his achievements that "If I have seen further it is by standing on the shoulders of Giants". Eysenck and Wolpe were such giants, and we should be grateful for their shoulders, and for the vision that their achievements allow us.

Paul Salkovskis 